be included in their curricula required courses that will give a sound basis for codes of life.

Most intelligent young people between the ages of seventeen and twenty desire an explanation of many of the accepted ethical principles. Many youths have worked out their own codes of living, which may be in direct conflict with accepted ideals. An individual's idea of right is not all that is necessary; society's demands are also important. If colleges required students to take courses in which were studied the "why's and wherefore's" of ethics, many young people would have less difficulty in adjusting themselves to life.

These courses should cover thoroughly the basic questions that arise in the minds of youth. Most young people wonder if there really is a God, if a good life is worth the effort, if the world is worth the supreme struggle of doing right, and, finally, just what the purpose of life is. All of these are answered fully in the Bible. Therefore why not use the Bible as a textbook? The examples in the New Testament in the form of parables are applicable to every-day life. The problems that faced the people of Jerusalem are no different from those which have to be faced today. Christ's life was an example of perfection to all. $\mathrm{He}$ taught by example. Therefore the instructors of these courses should exemplify two types.

The first should be an older person whose code of life has been mellowed by many years of living. He should be a brilliant man with universal knowledge and experience, whose word would be respected by students. He should be admired for his ability to solve the problems presented by students. It is this type of man who should lead the youth of today into a more gracious way of living.

The second should be a younger man who is known to be a "regular fellow." If he has seen the right way of life, people will want to follow him to a better way of living.

Most Christian colleges require courses in Bible. If taught in the proper way, this can be the most interesting course offered because it deals with the student's own problems. In Christian colleges this is almost a necessity. If the student objects to the forcing of religion on him, let him go to a state university where nothing of this kind can be required. In a college founded by the church, why not have religion a factor?

Many answers to social questions have been found in this Book which has offered a solution to every problem since its writing. Why not educate the college students with a workable knowledge that will help them solve the problems that will confront them in future life?

\title{
Compulsory Military Training
}

RHEA MCGOLDRTCK

The compulsory military training plan now before congress, but with little chance of immediate consideration, is one of great importance to us all. The fact that we were thrown into war, and were definitely unprepared, has made us fully realize that we should give some deep thought to the problem of future military training for our boys.

We Americans are divided into three groups on this subject. There are those completely opposed to compulsory mili- 
tary training, those who are in favor and yet believe a decision should be delayed until after the war, and those who belleve the plan should be modified and adopted now as an element in the national security.

Let us consider the first group, those who are completely opposed. They give the following reasons for such a stand:

First: Such a plan would interrupt the student's educational program, coming at the time when most boys are going from high school directly to college.

Second: Most decisions are made for boys in the service; they have too little chance to use their ingenuity.

Third: Life would become very serious for these young men with preparation for war beside them every minute.

Fourth: They are likely to become lazy.

Fifth: Some would feel a lack of interest in the program, since there would be no immediate crisis. They might feel the training was not necessary and that they were wasting their time.

Sixth: They would be temporarily detained from getting started in their life's work.

The second group are those who are in favor of the program and yet believe the decision should be delayed until after the war. Their reasons for such a stand are:

First: The men would be fully prepared in case of another war.

Second: In the service discipline is enforced and many boys at this age are in need of such supervision.

Third: The competitive spirit can prove stimulating with the men eager to advance in rank.

Fourth: The physical training program would be especially beneficial for all boys. Healthy bodies are the basis for happiness and success.

Fifth: Men would be taught the ability to get along with all types of people from every walk of life.

There are in the last group those who believe that the plan should be modified and adopted now as an element in the national security.

Of the last group I quote Dr. E. C. Elliott, president of Purdue University. Writing in the current issue of the American Legion magazine, he has this to say:

"At the moment I have the conviction that, as a nation, we must face the tragic and realistic fact that conditions approximating an enduring peace in the world are beyond early attainment - human natures, peoples, their governments and moralities being what they are, and are likely to be for many years to come. Meanwhile, we have the task of dreaming and energetically doing for peace. Meanwhile, too, we have the solemn and continuing obligation of being fully prepared for W (War) Day. Such preparation requires a comprehensive and closely knit program of national security. This program naturally includes industry, communication, transportation, food, national health and finance. Universal military training must be regarded as a part of a program of national security and must be carefully fitted into the whole of that program. The time to adopt the universal military training policy is now and not later."1

Upon discussing the opinions of the three groups I have reached the following decisions: I believe in military training of a limited degree, an intensified R. O. T. C. program working through the education systems. I would favor a pro- 
gram intensified enough to make sure that we could defend ourselves against future aggression, could at all times preserve our independence as a nation, and could preserve a world in which democr- acy may live.

1Dr. Edward C. Elliott, "An Educator Looks at U. M. T.," American Legion Magazine, Vol. 38, No. 5, p. 19.

\section{My Brother's Recital}

\section{BILl Dye}

The big night had arrived. My eightyear-old brother was to perform on the "eighty-eight" in his first recital. Tonight was the climax of a month of madness. Four long weeks had seen the rise and fall of the neighbors' patience. Day and night, night and day, all they heard was piano, piano, piano! They, as well as we, almost went mad. It would not have been too bad if $\mathrm{Al}$ could have played the piano without making it an instrument of torture. But his brand of music involved no more than two fingers, one on each hand.

When Al's music teacher first told him of the coming recital, $\mathrm{Al}$ had almost passed out of existence from nervousness. He play in a recital? Ridiculous! We thought so too. But the teacher convinced him otherwise. As time marched on, he became more confident of his abilities: the family gave up trying to discourage him.

Tonight all the parents and friends of the students had assembled to endure the agony with these budding virtuosos. I came prepared to enjoy myself. In one pocket was a deck of cards and in the other a pocket edition of "Captain Horatio Hornblower." I had been to these affairs before.

The choice of the place for the recital bordered on the sacrilegious. A fine old Methodist church was chosen as the victim. A majestic organ maintained its dignified aloofness in the left corner near the pulpit. The piano, unaware of its impending disgrace, was placed nonchalantly in the right corner. Dogwood stared open-eyed from the front of the auditorium at the audience.

When all was ready the pupils marched in from the right of the hall. The line started with the youngest and smallest and climbed up to the tallest - a girlwho brought up the rear. They took their places gingerly on the front rows and stood until all were in place. Then they all sat down as one body. The recital was about to begin.

In spite of my apparent unconcern, I began to get nervous. I had noticed that evening before leaving the house that $\mathrm{Al}$ 's confidence had left him. He was scared. So was I now. Captain Hornblower lay neglected in my pocket; the cards were still in the box. I sat on the edge of the pew and dug my fingernails into the wood in front of me. I am sure my parents shared $m y$ anxiety. Regardless of my slighting remarks about my brother's pianistic accomplishment I really felt proud of him and was eager to see him do well.

$\mathrm{Al}$, in the front row, was as pale as was Brutus upon beholding Caesar's ghost. And I noticed that in his right hand he clutched his music. This recital was supposed to be conducted entirely from memory. Why should $\mathrm{Al}$, then, have his music? He must have gone to pieces so completely that he was afraid to play 